\title{
CORRELATION BETWEEN LOCUS OF CONTROL WITH STRESS CARE OF NURSES IN HOSPITAL AT SOEBANDI HOSPITAL JEMBER
}

Erti Ikhtiarini Dewi ${ }^{1 *}$, Enggal Hadi Kurniyawan ${ }^{1}$, Afrize Rosalia $^{1}$

Afiliasi

1. Fakultas Keperawatan, Universitas Jember

Dikirim 9 Maret 2020

Direvisi 4 Agustus 2020

Diterima 6 Oktober 2020

Dipublikasikan 30 November 2020

*Corresponding author

Email :

arienta_d@yahoo.com

\begin{abstract}
ABSTRAK
Perawat merupakan tenaga kesehatan yang memiliki peran penting dalam rumah sakit. Perawat dapat mengalami stres kerja yang diakibatkan oleh banyaknya tugas dan pekerjaan yang tidak dapat terpenuhi. Beberapa faktor turut berkontribusi mempengaruhi stress kerja, salah satunya yaitu locus of control. Penelitian ini bertujuan untuk menganalisis hubungan antara locus of control dengan stres kerja pada perawat di RSUD dr. Soebandi Jember. Penelitian ini menggunakan desain korelasional dengan pendekatan cross-sectional. Jumlah sampel sebanyak 71 responden diperoleh dengan menggunakan teknik sampling purposive sampling. Pengumpulan data menggunakan kuesioner skala locus of control untuk mengukur locus of control dan kuesioner OSI-R (Occupatinal Stres Inventory-Revised Edition) untuk mengukur stres kerja perawat. Hasil penelitian didasarkan pada uji statistik Kendall tau dengan nilai p 0,032 dan nilai $r=-0,249$ yang berarti bahwa terdapat hubungan antara locus of control dengan stres kerja perawat, arah korelasi negatif dengan kekuatan korelasi yang lemah. Korelasi negatif menunjukkan bahwa semakin tinggi locus of control pada perawat, semakin rendah stres kerja yang dialami. Locus of control yang tinggi pada perawat memiliki dampak positif pada kualitas kerja perawat terutama dalam menjaga emosional seorang perawat dalam menjalankan tugas profesionalitasnya. Oleh karena itu rumah sakit sebaiknya dapat memberikan program pendidikan kesehatan tentang pentingnya locus of control maupun stres kerjapada perawat karena dapat berpengaruh terhadap kualitas asuhan keperawatan yang diberikan kepada pasien.
\end{abstract}

Kata Kunci : Locus of control, Stres Kerja

\begin{abstract}
Nurses are health workers who have an important role in the hospital. Nurses are professionals who have both positive and negative impacts. One of the negative impacts experienced by nurses is the work stress of nurses. Nurse work stress is a situation where nurses experience pressure caused by many tasks and jobs that cannot be fulfilled. In addition to the high workload, locus of control is also one of the factors that influence work stress on nurses. This study aimed to analyze the relationship between locus of control with nurses working stress in patients at dr. Soebandi Jember hospital. This study uses a correlational research design with a cross-sectional approach. A total of 71 respondents used a purposive sampling approach using the locus of control scale and OSI-R (Occupational Stress Inventory-Revised Edition). The statistical test used is Spearman. The results are based on the Kendall Tau statistical test with a p-value of 0.032 and a value of $r=-0.249$, which means that the relationship between locus of control and occupational nurses' work stress has a negative correlation direction with a weak correlation strength. A negative correlation shows that the higher the locus of control in nurses, the lower the work stress experienced by nurses. A high locus of control on nurses has a positive impact on the quality of work of nurses, especially in maintaining the emotional care of a nurse in carrying out professional tasks. Therefore the hospital should be able to provide health education programs about the importance of locus of control and work stress on nurses because it can affect the quality of nursing care provided to patients
\end{abstract}

Keywords: Job Stress, Locus of control

Sitasi jurnal :

Dewi EI, Kurniyawan EH, Rosalia A. 2020. Correlation between Locus Of Control With Stress Care Of Nurses In Hospital At Soebandi Hospital Jember. Jurnal Ilmu Keperawatan 8(2): 80-86 Doi: 10.21776/ub.jik.2020.008.02.3 


\section{PENDAHULUAN}

Perawat merupakan salah satu tenaga profesional dimana seseorang tersebut mempunyai pengetahuan, kemampuan, kewenangan dalam memberikan asuhan keperawatan terhadap klien dan memiliki peran otonomi sebagai wujud dari fungsi profesional keperawatan. Fungsi profesional digunakan untuk membantu mengkaji dan menentukan kebutuhan klien yang bersifat segera (Asriani, Mattalatta, \& Betan, 2016). Profesi keperawatan memiliki peran penting dalam rumah sakit karena perawat akan melayani pasien mulai dari bio-psiko-sosio-kultural-spiritual secara komprehensif serta perawat akan melakukan pelayanan dengan konsep asuhan keperawatan kepada individu, kelompok dan masyarakat dari sehat sampai sakit yang mencangkup seluruh proses kehidupan manusia (Persatuan Perawat Nasional Indonesia (PPNI), 2005).

Perawat memiliki pekerjaan yang tinggi sehingga mempunyai beberapa pengaruh yaitu pengaruh positif serta negatif. Pengaruh positif disini yaitu dengan terpenuhinya kebutuhan fisiologis sampai dengan kebutuhan aktualisasi diri bagi perawat dan klien. Pengaruh negatif yang diperoleh perawat dari pekerjaannya yaitu secara fisik dan psikis. Pengaruh negatif pada aspek fisik meliputi kelelahan, kecelakaan kerja, cedera dan terkontaminasi bahan kimia. Pengaruh negatif psikis yang diperoleh oleh seorang perawat salah satunya yaitu stress (Desima, 2013).

Stres kerja perawat ialah tekanan yang dialami oleh perawat yang diakibatkan oleh tugas atau banyaknya pekerjaan yang tidak dapat terpenuhi. Stres kerja perawat merupakan salah satu bentuk dampak negatif psikis yang sering dialami oleh perawat (Sulistyawati, Purnawati, \& Muliarta, 2019). Selain tuntutan kerja yang tinggi dari seorang perawat, terdapat situasi dimana perawat mengalami stres yaitu dengan adanya shift kerja, beban kerja perawat yang tinggi, faktor keluarga, resiko terkena infeksi, tempat tinggal yang jauh dari rumah sakit, fasilitas rumah sakit yang kurang memadai dan kemacetan lalu lintas saat menuju rumah sakit (Desima, 2013).

Hasil penelitian American National Assosiation for Occupational Health (ANAOH) menunjukkan bahwa stres kerja perawat berada di deretan paling tinggi dikarenakan tuntutan kerja perawat yang sangat penting yaitu memiliki tanggung jawab besar terhadap nyawa manusia. Penelitian tentang stres kerja pada perawat di ruang bedah RSD Wongsonegoro terdapat $59,5 \%$ perawat mengalami stres kerja yang diakibatkan karena beberapa faktor diantaranya beban kerja mental, beban kerja fisik dan peran seorang individu dalam suatu organisasi (Fuada., dkk,2017). Penelitian yang dilakukan oleh Health and Safety Executive (Health and Safety Executve, HSE, \& Health and Safety Executve, 2017) menjelaskan bahwa tenaga profesional contohnya, perawat dan guru mempunyai tingkat stres paling tinggi dengan jumlah prevalensi sebanyak 2500 pekerja pada tahun 2011, 2190 pekerja di tahun 2013 dan 3000 pekerja per 100.000 orang pekerja pada 2014/2015. Menurut (Pramadewi, Ningsih, \& Rahmadyrza, 2015) di Indonesia kejadian stres kerja perawat diperoleh sebanyak 44\% perawat mengalami stres kerja tinggi, $51,5 \%$ perawat mengalami stress kerja sedang dan sebanyak 51,2\% perawat di Intensive Care Unit (ICU) dan Instalasi Gawat Darurat (IGD) juga menjumpai stress kerja padaperawat.

Almasitoh (2011 dalam Pangestika, 2015) menjelaskan bahwa terbatasnya tenaga perawat jika dibandingkan dengan jumlah pasien maka akan berdampak pada kelelahan pada perawat. Faktorfaktor yang dapat mempengaruhi stres kerja perawat yaitu beban kerja tinggi, kelelahan, shift kerja perawat dan faktor keluarga (Sulistyawati et al., 2019). Selain itu salah satu faktor yang dapat mempengaruhi stres kerja pada perawat ialah locus of control (pengendalian diri) (Pangestika, 2015).

Locus of control merupakan cara pandang seseorang (persepsi) pada situasi yang dihadapi dalam kehidupan seseorang tersebut. Locus of control terdiri atas 2 karakteristik yaitu Locus of control internal dan Locus of control eksternal. Locus of control internal merupakan kondisi dimana seseorang yakin apa yang selalu terjadi pada dirinya selalu terkontrol dan seseorang yang memiliki keyakinan tersebut akan memiliki tanggung jawab besar pada setiap keputusan yang diambil tersebut. Sedangkan locus of control eksternal menunjukkan bahwa kejadian yang ada di dalam hidupnya tidak dapat terkontrol oleh diri individu tersebut (Sulistin, 2012).

Penelitian yang dilakukan di ruang rawat inap RS Muhammadiyah Palembang melalui metode wawancara, membuktikan bahwa perawat memiliki kontrol yang rendah terhadap perannya dan sulit untuk mengambil 
keputusan dalam pekerjaannya (Triwijayanti, 2016). Curiena (2013) menjelaskan bahwa hubungan antara locus of control eksternal dengan stres kerja perawat IGD memiliki signifikansi sedang, dengan ini membuktikan bahwa semakin tinggi stres kerja yang dihadapi perawat maka semakin tinggi juga seseorang itu dengan locus of control eksternalnya. Pinasti (Pinasti, 2011) juga menyampaikan teori bahwa seseorang dengan locus of control eksternal akan mengalami kesulitan untuk mengatasi stres dalam pekerjaannya.

Studi pendahuluan yang peneliti lakukan di RSD dr. Soebandi Jember menunjukkan bahwa jumlah perawat ruang rawat inap berjumlah 180 orang. RSD dr. Soebandi Jember mempunyai ruang rawat inap kelas 1, 2 dan 3 akan tetapi peneliti hanya mengambil ruang rawat inap di kelas 2 dan 3. Ruang rawat inap di kelas 2 dan 3 memiliki 10 ruang yang meliputi: Ruang Tulip, Sakura, Adenium, Anturium, Aster, Cateleya, Seruni, Edelwis, Melati, Mawar dan Gardena. Peneliti juga mendapatkan informasi bahwa disetiap ruang rawat inap memiliki 2 orang perawat ketua tim dan 1 orang karu serta 10-12 orang perawat pelaksana. Selain itu peneliti juga mendapatkan informasi dari kepala IRNA terkait stres kerja yang dialami perawat ruang rawat inap kelas 2 dan 3 lebih berat karena banyaknya pasien di ruang rawat kelas 2 dan 3 lebih banyak daripada ruang rawat inap kelas 1 . Oleh karena itu peneliti lebih memilih ruang rawat inap di kelas 2 dan 3 karena ruang rawat inap kelas 2 dan 3 memiliki kriteria yang diinginkan oleh peneliti dimana stres kerja yang dialami oleh perawat ruang rawat inap kelas 2 dan 3 lebih tinggi dengan beban kerja yang tinggijuga. Sehubungan dengan permasalahan diatas, peneliti perlu mengkaji tentang hubungan antara locus of control dengan stres kerja pada perawat ruang rawat inap di RSD dr. Soebandi Jember.

\section{METODE}

Penelitian ini merupakan penelitian korelasi dengan pendekatan cross sectional. Populasi dalam penelitian ini ialah perawat ruang rawat inap sejumlah 121 perawat. Peneliti menggunakan rumus Isaac dan Michael dalam menentukan besaran jumlah sampel, dan diperoleh 71 orang perawat. Teknik sampling yang digunakan adalah purposive sampling. Kriteria inklusi, meliputi: perawat pelaksana, perawat ruang rawat inap kelas 2 dan 3, dan bersedia menjadi responden.
Pengambilan data dilaksanakan pada bulan September - Oktober 2019 dengan menggunakan kuesioner skala locus of control dengan 7 indikator (kemampuan, minat, usaha, nasib, keberuntungan, sosial ekonomi dan pengaruh orang lain) dengan nilai Alpha Cronbach's $\geq 0,985$ (Triwijayanti, 2016). Peneliti juga menggunakan kuesioner OSI-R (Occupational Stress Inventory Resived) dengan 25 item pertanyaan dengan nilai $r$ hitung $=0,2$ dengan pilihan skor $1-4$ (Novianti, 2008 dalam Martina, 2012).

Variabel locus of control dengan stres kerja menggunakan skala data ordinal dengan menggunakan uji korelasi Kendall tau. Kelaikan etik penelitianditetapkan oleh KEPK Fakultas Kedokteran Gigi Universitas Jember dengan nomor 504/UN25.8/ KEPK/DL/2019. Prinsip etik dipatuhi pada penelitian ini diantaranya informed consent, menjaga kerahasiaan responden, serta berperilaku adil terhadap responden.

\section{HASIL}

Hasil penelitian berupa karakteristik yang terdiri dari jenis kelamin, tingkat pendidikan, lama bekerja dan status pernikahan. Selain itu hasil dari gambaran locus of control dan stres kerja beserta indikatorindikatornya disajikan dalam tabel dan narasi sebagai berikut:

Tabel 1: Karakteristik berdasarkan jenis kelamin, tingkat pendidikan, lama bekerja dan status pernikahan $(n=71)$

\begin{tabular}{lcc}
\hline \multicolumn{1}{c}{ Karakteristik } & $\mathrm{N}$ & $\%$ \\
\hline Jenis Kelamin & & \\
a. Laki-laki & 21 & 29,6 \\
b. Perempuan & 50 & 70,4 \\
\hline Lama Bekerja & & \\
a. 5-10tahun & 61 & 85,9 \\
b. 10-15tahun & 10 & 14,1 \\
\hline Tingkat Pendidikan & & \\
a. DIII & 64 & 90,1 \\
b. DIV & 3 & 4,2 \\
c. S1 & 3 & 4,2 \\
d. S2 & 1 & 1,4 \\
\hline Status Pernikahan & & \\
a. Menikah & 70 & 98,6 \\
b. TidakMenikah & 1 & 1,4 \\
\hline Total & 71 & $100 \%$ \\
\hline
\end{tabular}

Sumber : data primer yang diolah 
Tabel 1 menunjukkan bahwa karakteristik berdasarkan jenis kelamin mayoritas perempuan sebanyak 50 orang (70,4\%). Lama bekerja perawat mayoritas kurang dari 10 tahun yaitu 61 perawat $(85,9 \%)$. Sebagian besar perawat memiliki tingkat pendidikan terakhir yaitu DIII sebanyak 64 orang (90,1\%). Hampir secara keseluruhan responden sudah menikah yaitu sebanyak 70 (98,6\%) orang.

Tabel 2: Locus of control dan Stres Kerja perawat ruang rawat inap $\mathrm{RSD} d r$. Soebandi Jember $(n=71)$

\begin{tabular}{llcc}
\hline \multicolumn{1}{c}{ Variabel } & Kategori & $\mathrm{N}$ & $\%$ \\
\hline Locus of & 1.Tinggi & 36 & 50,7 \\
control & 2.Sedang & 35 & 49,3 \\
& 3.Rendah & 0 & 0 \\
\hline Stres & 1.Tinggi & 0 & 0 \\
Kerja & 2.Sedang & 10 & 14,1 \\
& 3.Rendah & 61 & 85,9 \\
\hline \multicolumn{1}{c}{ Total } & & 71 & 100 \\
\hline
\end{tabular}

Sumber: data primer yang diolah

Tabel 2 mendeskripsikan bahwa sebagian perawat memiliki locus of control tinggi sebanyak 36 (50,7\%) perawat dan yang memiliki locus of control sedang sebanyak 35 (49,3\%) perawat. Sedangkan pada nilai stres kerja, didapatkan mayoritas perawat ruang rawat inap mengalami stres kerja rendah sebanyak $61(85,9 \%)$ perawat dan yang mengalami stres kerja sedang sebanyak $10(14,1 \%)$ perawat.

Hasil uji kendall tau menunjukkan $\mathrm{p}$ value $=0,032$ yang berarti ada korelasi yang signifikan, namun nilai korelasi statistik lemah dengan nilai $\tau=-0,249$. Hal tersebut menunjukkan bahwa semakin tinggi locus of control maka semakin rendah stres kerja yang dialami oleh perawat ruang rawat inap RSD dr. Soebandi Jember.

\section{PEMBAHASAN}

\section{Karakteristik Responden}

Mayoritas perawat ruang rawat inap berjenis kelamin perempuan, dikarenakan bahwa lulusan akademi keperawatan berasal dari kelompok perempuan (Pramadewi et al., 2015). Profesi keperawatan telah membentuk stereotype bahwa profesi keperawatan lebih cocok pada gender perempuan daripada laki-laki, karena perempuan memiliki keluwesan lebih dibandingkan laki-laki saat melakukan pelayanan kesehatan contohnya seperti saat memandikan pasien (Prayoga, 2009).

Semakin lama masa kerja perawat maka semakin banyak pengalaman perawat tersebut dalam memberikan pelayanan serta memberikan asuhan keperawatan sesuai standar atau prosedur tetap yang berlaku. Semakin lama bekerja, maka keterampilan dan pengetahuan meningkat dan akan memperoleh pekerjaan yang lebih baik dan memiliki peluang lebih banyak untuk memperoleh pengakuan dan penghargaan yang akan memudahkan untuk mendapatkan wewenang (Maryati, 2018). Berdasarkan Undang-Undang keperawatan No. 38 tahun 2014 pasal 5 dan pasal 6 ayat 2 menyatakan bahwa pendidikan terendah perawat adalah pendidikan vokasi yakni pendidikan minimal DIII keperawatan (Keputusan Menteri Kesehatan Republik Indonesia Nomor :129/ menkes/SK/II/2008).

Penelitian yang dilakukan oleh Vierdelina (2008) menjelaskan bahwa stres kerja mayoritas terjadi pada responden yang sudah menikah $(55,8 \%)$ dibandingkan dengan responden yang belum menikah. Status perawat yang sudah menikah juga dapat membantu perawat untuk memahami dan membantu perawat untuk bersikap lebih dewasa dalam menghadapi masalah. Hal ini dikarenakan permasalahan yang sering terjadi pada keluarga, terutama karena sebagian besar responden merupakan keluarga muda yang masih memiliki anak usia balita.

\section{Locus of control}

Hasil penelitian menyebutkan bahwa perawat ruang rawat inap RSD dr. Soebandi Jember yang memiliki locus of control tinggi sebanyak 36 (50,7\%) dan yang memiliki locus of control sedang sebanyak 35 (49,3\%). Hal ini menunjukkan bahwa perawat ruang rawat inap memiliki locus of control yang tinggi yaitu mampu mengontrol diri dengan baik dalam keadaan tertentu. Penelitian ini didukung oleh penelitian (Linda, 2018) yang menunjukkan bahwa dari 30 responden, terdapat $19(63,3 \%)$ orang yang memiliki locus of control tinggi dan 11 (36,7\%) orang memiliki locus of control rendah. Penelitian yang dilakukan Pinori (2018) menunjukkan bahwa sebanyak 20 $(51,3 \%)$ orang memiliki locus of control tinggi, maka dari hasil penelitian tersebut perawat yang memiliki locus of control tinggi lebih banyak daripada locus of control rendah. 
Locus of control memiliki hubungan yang erat dengan perilaku, dimana individu dapat menerima kejadian-kejadian sebagai bagian dari perilaku atau karakteristik individu tersebut (Rahim, Kadir, \& Nontji, 2017). Perawat RSD dr. Soebandi memiliki locus of control yang tinggi dikarenakan perawat memiliki kepercayaan diri yang tinggi akan kemampuan yang dimilikinya, maka dari itu indikator kemampuan memiliki nilai mean (rata-rata) tertinggi. Namun, perawat tetap memerlukan peningkatan dalam segi sosial ekonomi sebagaimana penelitian yang dilakukan bahwa nilai terendah pada indikator sosial ekonomi, mungkin memerlukan adanya usaha sampingan selain dari pekerjaan tetap sebagai perawat untuk menambah penghasilan perawat dan menaikkan sosial ekonomi perawat. Oleh karena itu perawat RSD dr. Soebandi telah membuktikan bahwa perawat ruang rawat inapmemiliki profesionalitas yang tinggi terhadap pekerjaan yang mereka kerjakan tanpa menilai hasil/ upah yang mereka dapatkan sebagai status sosial ekonomi mereka.

\section{Stres Kerja}

Hasil penelitian menunjukkan bahwa stres kerja pada perawat ruang rawat inap berada dalam kategori rendah sebanyak 61 (85,9\%) dan tidak ada responden yang memiliki stres tinggi. Pada penelitian (Sari, Yusran, \& Ardiansyah, 2017) mendapatkan hasil bahwa stres kerja menunjukkan nilai mean (rata-rata) di bawah 2 maka dapat disimpulkan bahwa stres kerja perawat di ruang rawat inap RS X tidak terlalu tinggi atau rendah.

Potter \& Perry (2005) mengemukakan bahwa stres dibagi menjadi 3 yaitu stres ringan, stres sedang, dan stres berat. Stres ringan atau rendah merupakan suatu keadaan dimana seseorang mengalami tekanan namun hanya berlangsung beberapa jam saja. Peneliti berasumsi bawa perawat ruang rawat inap RSD dr. Soebandi hanya mengalami stres kerja rendah karena perawat memiliki kerjasama yang baik saat bekerja bukan hanya sebagai rekan tim tapi juga rekan perruangan rawatinap.

Penelitian (Adawiyah \& Blikololong, 2018) mengemukakan bahwa dukungan sosial yang diberikan oleh rekan kerja, baik dalam bentuk kenyamanan fisik ataupun psikologis seperti, dihargai, diperhatikan dan dicintai itu salah satu pemicu berkurangnya stres kerja, sehingga stres kerja yang dialami berada di tahap sedang atau bahkan ringan. Menurut Anastasia., dkk (2008) dampak dari stres kerja memiliki beberapa tingkatan yakni sedang dan tinggi, dimana pada tingkat tinggi memerlukan pengkajian ulang mengenai faktor-faktor penyebab terjadinya stres kerja. Jika seseorang pada tingkatan stres kerja sedang, didefinisikan bahwa orang tersebut masih bisa dikatakan mampu mengontrol stres kerja yang dihadapinya.

Perawat ruang rawat inap tidak mengalami stres berat/tinggi karena perawat RSD dr. Soebandi memiliki rekan kerja yang mendukung. Perawat ruang rawat inap RSD dr. Soebadi memiliki kerja sama yang sangat baik dan saling mendukung satu sama lain. Perawat juga menceritakan bahwa mereka masih mampu menyelesaikan tugas sebagai perawat dan tidak banyak mengeluh atas pekerjaannya. Oleh karena itu hasil yang didapatkan pada penelitian ini menggambarkan bahwa perawat ruang rawat inap tidak mengalami stres kerja tinggi namun hanya mengalami stres kerja sedang atau cenderung ke rendah.

\section{Hubungan Locus of Control dengan Stres Kerja}

Hasil penelitian yang dilakukan mendapatkan hasil bahwa $p$ value 0,032 kurang dari nilai significant 0,05 yang artinya terdapat hubungan antara locus of control dengan stres kerja perawat atau dapat dikatakan nilai Ha diterima. Penelitian ini juga mendapatkan nilai $\tau=-0,249$ yang dapat diartikan bahwa korelasi antara locus of control dengan stres kerja perawat memiliki arah korelasi negatif dengan kekuatan korelasi lemah. Korelasi negatif menunjukkan bahwa semakin tinggi locus of control pada perawat ruang rawat inap maka semakin rendah stres kerja yang dialami perawat.

Intam (2009) menyebutkan bahwa hubungan antara locus of control dengan stres kerja pada perawat di RSUD Undata Palu memiliki nilai $\mathrm{p}<0,05$. Korelasi pada penelitian ini lemah yang dapat diartikan bahwa hubungan antara locus of control dengan stres kerja perawat cenderung berhubungan namun sangat lemah. Hasil penelitian Triwijayanti (2016) menjelaskan bahwa adanya hubungan antara locus of control dengan burnout perawat dengan nilai $r=0,276$ yang dapat diartikan bahwa korelasi antara locus of control dengan burnout memiliki arah korelasi positif. Korelasi positif menunjukkan bahwa semakin tinggi locus of 
control perawat maka semakin tinggi juga burnout yang dimiliki oleh perawat.

Perawat ruang rawat inap RSD dr. Soebandi dapat mengontrol diri untuk mengurangi stres kerja yang kemungkinan muncul pada saat bekerja. Sebagaimana yang tergambar dan terlihat oleh peneliti bahwa perawat ruang rawat inap selalu melakukan tugasnya dengan percaya diri yang tinggi serta sabar dan tekun. Oleh karena itu perawat ruang rawat inap cenderung tidak mengalami stres kerja tinggi, dikarenakan salah satu faktor locus of control mereka tinggi begitu pula dari beberapa indikator locus of control sudah menggambarkan bahwa perawat memiliki kepercayaan diri yang tinggi pada indikator kemampuan dan usaha, akan tetapi tidak menutup kemungkinan bahwa indikator locus of control mengenai pengaruh orang lain dapat mempengaruhi stres kerja perawat.

\section{DAFTAR PUSTAKA}

Adawiyah, R., \& Blikololong, J. B. (2018). Hubungan antara Dukungan Sosial dan Burnout pada Karyawan Rumah Sakit.Jurnal Psikologi. https:// doi.org/10.35760/psi.2018.v11i2.2264

Anastasia, Mariyono SW, Syahirul A. (2008). Hubungan Kecerdasan Emosional dengan Tingkat stres Kerja Perawat. 3(1). AIPNI. 2010. Kurikulum KBK AIPNI Jakarta.

Asriani, Mattalatta, \& Betan, A. (2016). Pengaruh Penerapan Model Praktek Keperawatn Profesional (MPKP) terhadap Standar Asuhan Keperawatan dan Kepuasan Kerja Perawat di Ruang Rawat Inap Rumah Sakit Bhayangkara Makassar. Jurnal Mirai Management. https:// doi.org/https://doi.org/10.1234/mirai.v2i1.33

Caesaria, Dima Wuenta. (2010). Hubungan Antara Dukungan Sosial dengan Stres Kerja Karyawan Bagian Produksi PT. Industri Karet Nusantara. Universitas Sanata Dharma Yogyakarta.

Curiena, Makikama.,dkk. (2014). Hubungan antara Locus of Control dengan Suasana Kerja dan Stres Kerja Perawat Instalasi Rawat Jalan (Poliklinik) RSUP. Prof. DR. R. D. Kandou Manado. Fakultas Kesehatan Masyarakat: Universitas Sam Ratulangi

Desima, R. (2013). Tingkat stres kerja perawat dengan perilaku caring perawat. Jurnal Keperawatan.

\section{KESIMPULAN}

Berdasarkan hasil dan pembahasan dalam penelitian yang telah dilakukan, dapat disimpulkan bahwa sebagian responden memiliki locus of control dengan kategori tinggi (50,7\%). Mayoritas perawat berada dalam kategori stres kerja rendah (85,9\%). Terdapat hubungan antara locus of control dengan stres kerja perawat ruang rawat inap, memiliki korelasi negatif dimana semakin tinggi locus of control maka semakin rendah stres kerja yang dialami perawat ruang rawat inap RSD dr. Soebandi Jember.

Saran bagi peneliti selanjutnya yakni dapat mencari korelasi antara beban kerja dengan stres kerja perawat ruang rawat inap. Institusi pelayanan kesehatan sebaiknya dapat memberikan program pendidikan tentang pentingnya locus of control maupun stres kerja terutama pada perawat ruang rawat inap.

Fuada.,dkk. (2017). Faktor-Faktor yang Berhubungan dengan Stres Kerja pada Perawat Kamar Bedah di Instalasi Bedah Sentral RSD K.R.M.T Wongsonegoro Semarang. Jurnal Kesehatan Masyarakat. 5(5)

Health and Safety Executve, HSE, \& Health and Safety Executve. (2017). Work-related Stress, Depression or Anxiety Statistics in Great Britain 2017. Health and Safety Executive Report.

Intam, Muhammad Nur.S. (2009). Hubungan Locus of Control dan Konsep Diri dengan Stres Kerja pada Perawat di Rumah Sakit Umum Daerah Undata Palu. Program Studi Psikologi: Uniersitas Negeri Malang

Linda, L. (2018). Faktor - Faktor yang Berhubungan dengan Stres Kerja Perawat di Instalasi Gawat Darurat RSUD Ulin Banjarmasin. HealthyMu Journal. https://doi.org/10.35747/hmj. v2i1.154

Pangestika, Widya Putri. (2015). Hubungan Internal Locus of Control dengan Stres Kerja Perawat Bagian Unit Gawat Darurat. Universitas Katolik Soegijapranata Semarang: Fakultas Psikologi.

Persatuan Perawat Nasional Indonesia (PPNI). (2005). Standar Kompetensi Perawat Indonesia. Standar Kompetensi Perawat Indonesia- Di Publikasi Oleh Bidang Organisasi PP-PPNI Melalui; Http:// Www.Inna-Ppni.or.Id. 
Pinasti, W. (2011). Pengaruh Self-efficacy, Locus of Control dan Faktor Demografis Terhadap Kematangan Karir. Universitas Islam Negeri Syarif Hidayatullah Jakarta.

Pinori, Sara Novi. (2018). Hubungan Antara Locus of Control dengan Emotional Quotient (EQ) dengan Kelelahan Kerja Perawat di RS Bhayangkara TK.III Manado. E- Journal Keperawatan (e-Kep). $6(1)$.

Pramadewi, A., Ningsih, D., \& Rahmadyrza, M. (2015). Faktor-faktor yang Mempengaruhi Munculnya Stres Kerja Perawat di Ruang Rawat Inap Cendrawasih RSUD Arifin Ahmad Provinsi Riau Pekanbaru. Jurnal Online Mahasiswa Fakultas Ekonomi Universitas Riau.

Prayoga, Guntur. (2009). Kesetaraan Gender Perawat Laki-Laki dan Perempuan Dalam Pelayanan Kesehatan. Fakultas Ilmu Sosial \& Ilmu Politik: Universitas Sebelas Maret.

Rahim, R., Kadir, A. R., \& Nontji, W. (2017). Hubungan Locus of Control dengan Komitmen Organisasi Perawat di Ruang Rawat Inap Rumah Sakit. Jurnal Kesehatan Manarang. https://doi. org/10.33490/jkm.v2i1.6
Sari, R., Yusran, S., \& Ardiansyah, R. (2017). Faktor yang Berhubungan dengan Stres Kerja pada Perawat di Ruang Rawat Inap Rumah Sakit Jiwa Provinsi Sulawesi Tenggara Tahun 2016. Jurnal Ilmiah Mahasiswa Kesehatan Masyarakat Unsyiah.

Sulistin, Y. (2012). Hubungan Antara Locus of Control dengan Kepuasan Kerja pada Perawat di Puskesmas Sumobito Kabupaten Jombang. Fakultas Psikologis: Universitas Islam Negeri Maulana Malik Ibrahin Malang.

Sulistyawati, N. N. N., Purnawati, S., \& Muliarta, I. M. (2019). Gambaran Tingkat Stres Kerja Perawat dengan Kerja Shift di Instalasi Gawat Darurat RSUD KARANGASEM. E-Jurnal Medika Udayana. https://doi.org/10.24922/eum.v8i1.45222

Triwijayanti, Renny. (2016). Hubungan Locus of Control dengan Burnout Perawat di Ruang Rawat Inap Rumah Sakit Muhammadiyah Palembang. Fakultas Kedokteran: Universitas Diponegoro

Viedelina, N. (2008). Gambaran Stres Kerja dan FaktorFaktor Yang Berhubungan Pada Pengemudi Bus Patas 9B Jurusan Bekasi Barat-Ciliwung/ Kampung Rambutan Jakarta. Junal Kesehatan Masyarakat. Universitas Indonesia. 